\title{
PENINGKATAN KEMAMPUAN MENULIS ANAK USIA DINI DENGAN MENGGUNAKAN METODE MENIRU TULISAN
}

\author{
Chairunnisa dan Ahmad Ari Masyhuri \\ STKIP Kusumanegara Jakarta \\ Universitas Pamulang \\ Chairunnisa.khis@stkipkusumanegara.ac.id \\ arymasyhuri@gmail.com
}

\begin{abstract}
Abstrak
Mengetahui pengembangan kemampuan motorik halus melalui kegiatan meniru pada anak usia dini, merupakan tujuan dari hasil penelitian tindakan kelas (PTK) ini, melalui riset langsung dengan sampel kelompok B di PAUD Ar-Rohman Jakarta Timur Tahun Ajaran 2018/2019. Metode yang digunakan adalah metode meniru tulisan, teknik pengumpulan data yaitu dengan observasi dan dokumentasi. Penelitian ini dilaksanakan dalam 3 siklus dalam 3 hari penelitian terdiri dari 4 tahap, yaitu: perencanaan, tindakan, observasi dan refleksi. Siklus pertama yaitu pertemuan. Teknik analisis komparatif untuk membandingkan kemampuan anak setiap siklusnya yaitu dengan persentase keberhasilan. Hasil penelitian ini menunjukkan terjadi peningkatan 5\% tiap siklus yaitu akhir hasil terdapat 37 peserta didik mengalami peningkatan menulis yang cukup signifikan, dibandingkan pada observasi awal hanya 17 peserta didik dari 40 yang mampu menulis. Hal ini menunjukkan bahwa kemampuan motorik halus anak mengalami peningkatan melalui kegiatan meniru tulisan. Ini dapat dilihat dari persentase hasil observasi kemampuan motorik halus anak.
\end{abstract}

Kata Kunci: Motorik Halus Anak, Metode Meniru Tulisan, PTK.

\section{PENDAHULUAN}

$\mathrm{P}$

entingnya menulis bagi anak usia dini adalah sebagai berikut:

secara umum, budaya menulis memiliki banyak manfaat.

Diantaranya sebagai media penyaluran emosi maupun ekspresi dirik, belajar beropini, melatih kesabaran, mengasah komitmen, dan banyak lagi. Seperti menggambar atau melukis, menulis juga bermanfaat melatih kreativitas dan mengembangkan imajinasi.

Sedangkan beberapa manfaat yang dapat di petik dari menulis dalam Suparno dan Yunus (2002:1.4) di antaranya:

1. Peningkatan kecerdasan ;

2. Mengembangkan daya inisiatif dan kreatif; 
3. Menumbuhkan keberanian; dan

4. Mendorong kemauan dan kemampuan mengumpul informasi.

Pendidikan anak usia dini merupakan salah satu bentuk penyelenggaraan yang membantu pertumbuhan dan perkembangan jasmani dan rohani agar anak memiliki kesiapan memasuki pendidikan lebih lanjut. Aspek perkembangan anak usia dini yaitu perkembangan motorik halus salah satunya kegiatan menulis.

Dalam pengelolaan lembaga PAUD yang masih menjadi persoalan adalah mengenai kurikulum yang didapatkan. Kebanyakan pengelola masih ingin mengajari anak usia dini dalam tiga hal yakni: membaca, menulis dan berhitung. Persoalan membaca dan menulis memang merupakan fenomena tersendiri yang serba delematis. Pada umumnya orang tua, yang memiliki anak usia dini yang dididik di Taman Kanak-Kanak merasa khawatir anak-anaknya tidak mampu dan sulit mengikuti pelajaran di Sekolah Dasar (SD), jika dari awal belum dibekali dengan membaca dan menulis. Karenanya banyak orang tua yang mengharapkan anaknya untuk segera diajarkan membaca dan menulis.

Kemampuan pra menulis anak usia dini merupakan priode perkembangan yang cepat yang terjadi dalam banyak aspek perkembangan yang dimiliki potensi yang masih harus dikembangkan. Periode ini sering pula disebut usia prasekolah. Aspek kehidupan pada anak, seperti mengenalkan kerajinan tangan: musik, alam sekitar, huruf, angka dan lain sebagainya. Tentunya dengan kegiatan yang asyik dan menyenangkan.

Tingkat pencapaian perkembangan dalam permen Diknas No. 58. 2009 adalah menggunakan alat tulis dengan benar, meniru bentuk, menggunting dengan pola, juga nulis nama sendiri. Menulis termasuk salah satu keterampilan berbahasa. Tarigan. H. G. (2008 : 1) mengungkapkan bahwa keterampilan bahasa itu mencangkup empat komponen yaitu menyimak, berbicara, membaca dan menulis. Dari empat kemampuan itu ada satu komponen yang harus dilatih secara berkesinambungan yaitu kemampuan menulis. 
Keterampilan menulis adalah kemampuan mengepresikan pikiran melalui lambang-lambang tulisan. Henry Guntur Tarigan (2009.23) mengartikan "Keterampilan menulis adalah meniru atau melukiskan lambang-lambang bilangan yang menggunakan suatu bahasa yang dipahami oleh seseorang". Kemampuan menulis pemula tidak jauh berbeda dengan dengan kemampuan membaca pemula. Pada tingkat dasar permulaan, pembelajaran menulis lebih di orientasikan pada kempuan mengenal simbol huruf.

Secara umum anak sudah melakukan kegiatan menulis sebelum anak-anak masuk sekolah atau sebelum anak menerima pembelajaran menulis secara formal disekolah. Hal ini bisa dilihat ketika anak melihat alat tulis, seperti pensil, bolpen, spidol, krayon secara spontanitas anak akan menggunakan alat tulis tersebut untuk menulis walaupun yang dibuat bentuk corat-coretan yang tidak jelas dan bentuk benang kusut.

Sedangkan menurut Dhieni (2005) yaitu "Perkembangan menulis pada anak usia dini dimulai dari cara anak memegang pensil untuk mencoret-coret, namun seiring perkembangannya anak akan mengkonsentrasikan jari-jari untuk menulis lebih baik". Umumnya kemampuan menulis anak TK (prasekolah) yang mendapatkan stimulasi baik berada pada usia 3-4 tahun atau 5 tahun ini adalah hal yang baik. Sebagai pendidik tidak bisa mengharapkan semua anak usia prasekolah mencapai kemampuan itu. Dengan stimulasi yang tepat guru dapat membimbing anak dalam kegiatannya. Secara umum mengajarkan anak menulis adalah agar anak mampu dengan persyaratan menulis secara jelas yaitu dengan karakter-karakter huruf yang jelas dan sesuai dengan aturan yang berlaku. Untuk memudahkan anak agar bisa menulis, guru perlu menggunakan berbagai media sehingga anak tertarik dengan kemampuan menulisnya dapat berkembang dengan baik.

\section{TINJAUAN TEORITIS}

\section{Kemampuan Menulis}

\section{Pengertian Stimulasi Bahasa Tulis}

Pembelajaran bahasa merupakan sebuah proses internalisasi sistem (Chairunnisa, 125: 2018), maka dari itu perlu ada stimulasi untuk pengembangannya. Stimulasi bahasa tulis berarti merangsang 
anak untuk mengenali, memahami, dan menggunakan simbol tertulis dari bahasa atau langue-nya untuk berkomunikasi sesuai dengan tahap perkembangannya. Rangsang diberikan dalam berbagai bentuk, mulai dari pemajanan bentuk hingga produksi. Stimulasi bahasa tulis bukanlah mengajarkan menulis dan membaca. Stimulasi bahasa tulis bertitik fokus pada memberi tangsang literasi visual dan berbal aga dimanfaatkan seoptimal mungkin oleh anak untuk mengekspresikan ide dan perasaannya. Muara yang dituju adalah agar anak dapat mewujudkan fungsi-fungsi bahasa dalam bentuk simbol tulis sesuai tingkap penguasaannya.

Stimulasi mendorong pemerolehan atau akuisisi, yakni bentuk penguasaan simbol tulis secara alami. Oleh karena itu, stimulai bahasa tulis mensyaratkan pengetahuan tentang tahap pencapaian anak. Tahap ini dapat diketahui melalui aktivitas "menginterpretasi" simbol tulis dan "menyusun" pesan dalam simbol tulis tersebut. Apa yang ditunjukkan anak secara bebas (tidak di bawah instruksi) itulah tahap pemerolehannya.

Stimulasi memiliki makna mendorong minat baca, menyediakan lingkungan literat yang siap dieksplorasi oleh anak, menumbuhkan kesadaran fonemik, mendorong munculnya kesadaran grafemis, kesadaran grafofonemis, untuk bekal membaca. Hal ini sesuai dengan riset yang dilakukan oleh Adam (1990); Goswani dan Bryand (1990) yang menunjukan bahwa anak usia 3-5 tahun yang memiliki kesadaran rima, grafem awal, bunyi grafem, dan nama huruf yang menyusun kata memiliki kemajuan membaca yang lebih baik daripada yang tidak. Stimulasi memiliki makna: mendorong anak untuk mengekspresikan ide dan pengalamannya melalui simbol visual yang secara bertahap mengacu pada simbol linguistik yang konvensional, dalam hal ini adalah grafem bahasa Indonesia.

\section{Mengapa Stimulasi}

Stimulasi berarti membangkitkan sesuatu kekuatan atau kemampuan yang sebenarnya telah ada dalam diri seorang anak. Stimulasi tidak bersifat memaksa dan tidak mengandung target kemampuan tertentu (bukan merupakan bagian dari teacher centre) 
sebagai indikator keberhasilan. Stimulasi memiliki kesejajaran konsep dengan mendorong atau merangsang. Stimulasi mengandung konsep "merangsang atau mendorong anak menjadi untuk kenal, tahu, dan paham".

Proses stimulasi mengandung arti mendorong anak mengetahui sesuatu secara langsung. Proses stimulasi dipengaruhi oleh tingkat atensi anak. semakin besar atensi anak, semakin baik kemungkinan anak mengenal sesuatu. Stimulasi bersifat individual. Artinya, fitur apa yang menarik minat anak dan bagaimana fitur itu difungsikan, sangat ditentukan oleh anak. Dari mana dan materi apa yang dielaborasi kemudian oleh anak, sangatlah individual sifatnya. Guru dan orangtua dapat memberikan dukungan dan bantuan, tepat pada saat anak membutuhkan.

Merangsang dan mengenalkan bukanlah mengajarkan. Tidak ada target eksternal dalam stimulasi dan mengenalkan. Guru tidak boleh membuat menyamarataan capaian bahasa tulis anak karena apa yang ingin "dibaca" dan "ditulis" oleh setiap anak didasarkan pada kebutuhan individual anak. Artinya, capaian anak tidak bersifat homogen. Berbahasa tulis merupakan bagian dari kecakapan hidup anak. dalam wujudnya yang spesifik, yakni membaca dan menulis, bahasa tulis (Sulzby dan Teale (1991), didasarkan pada gagasan berikut.

a. Anak, belajar bahasa secara alamiah. Membaca dan menulis merupakan perluasan alami dari pemerolehan bahasa;

b. Membaca dan menulis dipengaruhi oleh bagaimana anak berinteraksi dengan lingkungan;

c. Orang dewasa sangat mempengaruhi kemunculan bahasa tulis anak. Oleh karena itu, orang tua perlu meneyediakan lingkungan penuh buku dan bacaan yang memungkinan anak berinteraksi dengannya;

d. Membimbing bahasa tulis anak haruslah peka dengan aspek perkembagnan anak. Riset yang dilakukan Kutiper dan Wilson (1993) menunjukkan bahwa anak akan mudah diperkenalkan 
tulisan seperti puisi yang mengandung ritme, irama, humor, langsung, dan struktur naratifnya sudah dikenal anak;

e. Bahasa tulis pada anak-anak merupakan suatu periode awal pembelajaran, yang ketika masa itu dijaga, akan memperkuat proses pembelajaran (kelak) di sekolah formal. Pada masa itu anak-anak membangun sendiri kategori-kategori informasi yang disebut "skemata", yang membentuk dasar untuk kegiatan belajar selanjutnya.

\section{Prinsip Stimulasi Bahasa Tulis pada Anak}

Stimulasi yang paling baik diberikan pada masa anak-anak adalah melalui bermain, karena bermain adalah sumber perkembangan dan membentuk zone of proximal development (ZPD) (Vygotsky, 1967). Dalam bermain terjadi proses representasi simbolik, ekspresi artistik, menemukan manfaat (rewarding) dan cara yang tepat (appropriate) untuk berinteraksi dengan orang lain (Bronson, 1999: 3).

Proses belajar, menurut pandangan konstruktivistik harus menekankan keterlibatan anak. Menurut pandangan ini, proses belajar haruslah menyenangkan bagi anak anak dan memungkinkan mereka berinteraksi secara aktif dengan lingkungannya. Bermain, merupakan media sekaligus cara terbaik anak utnuk belajar. Dalam bermain itulah anak belajar melalui proses berbuat dan menyentuh langsung objek-objek nyata. Anak tidak belajar banyak melalui interpretasi stimulasi verbal (kata-kata) dari orang yang lebih dewasa.

\section{METODOLOGI PENELITIAN}

Di dalam penelitian ini yang diambil adalah motorik halus. Karena kegiatan motorik halus sangat penting dikembangkan di Taman Kanak-kanak sebab motorik halus bertujuan untuk melatih koordinasi mata anak, melatih kelenturan jari-jemari tangan dan persiapan untuk menulis, keseimbangan, kelincahan, dan melatih keberanian.

Namun, kenyataannya bersadarkan pengamatan yang peneliti lakukan di Kelompok B PAUD Ar-Rohman tahun ajaran 2018/2019 peneliti menemui berbagai fenomena. Dalam pelaksanaan kegiatan pembelajaran ditemukan perkembangan motorik halus anak belum 
semuanya berkembang, hal ini terlihat saat melaksanakan kegiatan meniru garis dengan pensil, dimana masih banyak terlihat anak yang cara memegang pensil masih kaku dan bahkan ada beberapa dari mereka sudah mampu tapi masih kaku untuk menggerakkan jari-jemarinya secara terkontrol. Hal ini disebabkan karena metode yang digunakan tidak bervariasi, media yang digunakan kurang menarik hanya menggunakan pensil biasa, kemampuan guru menciptakan kegiatan motorik halus masih kurang.

Langkah-langkah untuk mengatasi masalah tersebut, peneliti tertarik untuk melakukan penelitian dengan judul "Meningkatkan Kemampuan Menulis Anak Usia Dini Dengan Menggunakan Metode Meniru Tulisan" Pengembangan Kemampuan Motorik Halus melalui Kegiatan Meniru Tulisan pada Anak Kelompok B PAUD Ar-Rohman Jakarta Timur Tahun Ajaran 2018/2019” yang sangat dibutuhkan anak untuk kelenturan jari-jemari tangan dan pergelangan sehingga motorik halus anak akan berkembang dengan maksimal. Menurut Fajri dalam Kamus Lengkap Bahasa Indonesia (2005: 309) mengatakan meniru garis adalah kegiatan membuat bermacam garis dalam sebuah bentuk gambar yang telah disediakan. Berdasarkan pernyataan di atas dapat disimpulkan bahwa kegiatan meniru garis dapat mengembangkan motorik halus.

Penelitian ini melakukan metode meniru tulisan yang titik tekannya pada pengembangan motorik halus anak melalui meniru tulisan pada Anak. Objek penelitian di Kelompok B PAUD Ar-Rohman Jakarta Timur, sebanyak 40 peserta didik.

\section{HASIL TEMUAN}

\section{Pembahasan Membaca Dan Menulis Bagi Anak}

Begitu pentingnya membaca dan menulis bagi anak usia dini untuk melanjutkan ke jenjang pendidikan Sekolah Dasar (SD). Di PAUD AR-Rohman sendiri sudah mulai dikenalkan huruf abjad, angka untuk melatih membaca, berhitung dan menulis. Namun berdasarkan observasi awal peneliti lihat masih ada 17 peserta didik yang belum berkembang dalam kemampuan permulaan menulisnya dari 40 peserta didik kelompok A dan B yang berusia 4-5 tahun. Hal inilah yang membuat peneliti tertarik untuk mengambil judul "Meningkatkan Keterampilan 
Menulis Anak Usia Dini Dengan Menggunakan Metode Meniru Tulisan".

Penelitian ini dilaksanakan di TK AR-Rohman yang beralamat di Jalan Nangka Ceger Cipayung Jakarta Timur. Peneliti melakukan observasi yang digunakan oleh untuk mengetahui aktivitas anak dan guru selama pembelajaran. Observasi dilakukan untuk mengetahui sampai dimana peningkatan berbahasa dan menulis anak dalam pembelajaran di kelas. Peneliti juga mengadakan wawancara dengan guru pendidik PAUD AR-Rohman, agar memperoleh data yang lebih obyektif dan akurat tentang penerapan pembelajaran meningkatkan keterampilan menulis anak usia dini dengan menggunakan metode meniru tulisan. Peneliti juga mewawancarai anak-anak untuk mengetahui kelancaran berbahasa anak dan selain itu melakukan dokumentasi.

Kemampuan dasar yang diambil dalam pembahasan ini adalah kemampuan dasar fisik. Fisik terbagi dua yaitu motorik kasar dan motorik halus. Motorik kasar adalah gerakan yang dilakukan semua anggota tubuh yang banyak mengeluarkan tenaga seperti melompat, berlari, merangkak, berjalan cepat, berjinjit, berjalan dengan titian. Motorik halus adalah gerakan yang dilakukan sebagian anggota tubuh (jemari tangan) yang mengeluarkan sedikit tenaga seperti: meremas, menulis, dll. Sesuai dengan pendapat Sujiono (2008: 1.14) mengatakan motorik halus adalah gerakan yang hanya melibatkan bagian-bagian tubuh tertentu saja dan dilakukan oleh otot-otot kecil.

Peneliti melakukan pengamatan Anak Usia Dini di PAUD ARRohman sebanyak 3 kali di hari yang berbeda dan minggu yang berbeda yaitu: mingu pertama dihari senin ketika kegiatan pembelajaran menulis huruf abjad, minggu ke dua dihari selasa, ketika kegiatan pembelajaran menulis angka, sedangkan minggu ke tiga dihari rabu, ketika kegiatan pembelajaran menulis huruf hijaiyah. Namun peserta didik belum bisa menulis dengan baik dan lancar, dikarenakan pembelajaran menulis yang diterapkan oleh guru mereka dengan cara mengikuti tulisan yang dicontohkan di papan tulis. 
Tulisan yang dicontohkan dipapan tulis berupa huruf A B C D sampai dengan Z, kemudian angka 12345 sampai dengan 10. Cara seperti ini sangat menyulitkan peserta didik untuk mengikutinya, akhirnya anak-anak teriak memanggil ibu gurunya untuk membantu mereka menulis, Ibu gurupun dengan sabar menuntun anak satu persatu dalam menulis. Kegiatan menulis seperti ini tidak akan bisa mengahasilkan tulisan dengan baik dan rapi. Hal seperti ini dikhawatirkan peserta didik akan sulit dan lambat untuk bisa menulis dengan rapi dan lancar, ketika anak melanjutkan pendidikan di Sekolah Dasar (SD). Sedangkan di Sekolah Dasar (SD) diharuskan sudah bisa lancar membaca, menulis dan berhitung.

Berdasarkan hasil pengamatan peneliti di atas, dalam mengamati kegiatan pembelajar peserta didik. Peneliti mulai menerapkan peningkatan keterampilan menulis anak dengan menggunakan metode meniru tulisan, dengan cara memberi kertas yang berisikan bentuk tulisan yang belum sempurana yaitu: bentuk dititik-titik pada huruf abjad, angka, dan huruf hijaiyah. Kemudian mereka menebalkannya dengan meniru atau mengikuti bentuk huruf dan angka yang sudah diberi titik-titik terlebih dahulu. Anak-anakpun terlihat senang menulis dengan metode meniru tulisa tersebut. Karena mereka lebih mudah dan lancar dalam melakukan gerakan menulis. Begitu juga dengan gurunya mereka sangat senang melihat peserta didiknya sudah mulai lancar menulis. Guru sangat berterima kasih kepada peneliti yang telah menerapkan keterampilan menulis dengan menggunakan metode meniru tulisan. Sehingga mempermudah mereka mengajar dalam kegiatan pembelajaran menulis.

Hasil pengamatan terakhir, peneliti merasa senang melihat peserta sudah mulai lancar dalam menulis. Bahkan ada beberapa anak sangant suka dengan cara menulis meniru tulisan. Kadang mereka meminta dibuatkan lagi tulisan yang beri titik-titik terlebih seperti yang diterpakan oleh peneliti. Penerapan metode yang dilakukan peneliti dalam Peningkatan keterampilan menulis anak dengan metode meniru tulisan di PAUD AR-Rohman berjalan lancar dan hasilnya pun sangat memuaskan. 


\section{SIMPULAN}

Pendidikan anak usia dini merupakan salah satu bentuk penyelenggaraan yang membantu pertumbuhan dan perkembangan jasmani dan rohani agar anak memiliki kesiapan memasuki pendidikan lebih lanjut. Aspek perkembangan anak usia dini yaitu perkembangan motirik halus salah satunya dengan kegiatan menulis.

Keterampilan menulis adalah kemampuan mengekspresikan pikiran melalui lambang-lambang tulisan. Henry Guntur Tarigan (2009.23) mengartikan "keterampilan menulis adalah meniru atau melukiskan lambang-lambang bilangan yang menggunakan suatu bahsa yang dipahami oleh seseorang". Berbahasa tulis merupakan bagian dari kecakapan hidup anak.Stimulasi paling baik yang diberikan pada masa anak-anak adalah melalui bermain,dalam bermain itulah anak belajar melalui proses berbuat dan menyentuh langsung objek-objek nyata.

Peneliti melakukan pengamatan anak usia dini di PAUD Arrohman sebanyak tiga kali dihari yang berbeda ketika kegiatan pembelajaran menulis. Berdasarkan hasil pengamatan, peneliti mulai menerapkan peningkatan keterampilan menulis anak dengan menggunakan metode meniru tulisan yaitu dengan cara menebalkannya dengan meniru atau mengikuti bentuk huruf dan angka yang sudah diberi titik-titik terlebih dahulu.

Hasil pengamatan terakhir, peneliti melihat sebanyak 32 peserta didik sudah mulai lancar dalam menulis. Sehingga manfaat penelitian ini adalah bagi anak dapat mengembangkan motorik halus, bagi guru dapat memperoleh pengalaman dan pengetahuan tentang upaya pengembangan motorik halus anak, bagi sekolah dapat mengembangkan kualitas pendidikan dan proses belajar mengajar serta bagi masyarakat dapat memberikan pemahaman dalam mengembangkan motorik halus anak.

\section{DAFTAR PUSTAKA}

Chairunnisa, M.Pd. "Pemerolehan Bahasa Pada Bayi Dan Anak". Pada

Cakrawala Jurnal Pendidikan. Vol 9, no. 2. Bandung. 2018 
Dhieni, dkk. Metode Pengembangan Bahasa. Jakarta: Universitas Terbuka. 2007.

Feldman, J.R. A Survival Guide For The Preschooler Teacher. New York: The Centre For Aplied Research in Education. 1991.

Marrow, Lesley Amdel. Literacy Development in the Early Years. USA: Allyn \& Bacon a Division of Simon \& Schuster, inc. 1993.

Musfiroh Tadkiroatun. Menumbuhkembangkan Baca Tulis Anak Usia Dini. Jakarta: Grasindo. 2009.

Tarigan, H.G. Membaca Sebagai Suatu Keterampilan Berbahasa. Bandung: Angkasa. 2008.

Tarigan. Pengajaran Ejaan Bahasa Indonesia. Bandung: Angkasa. 2009. 